\title{
Relevance versus Reliability Trade-off in Financial Reporting among Companies Listed at Visegrad Group Stock Exchanges
}

\author{
Libor Závodny"
}

\begin{abstract}
:
The objective of this study is to examine the relevance and reliability aspects of accounting with respect to earnings' usefulness which is measured as the association between earnings and share returns. Motivated by the lack of this research in emerging markets, this paper is focused on the companies listed on the stock exchanges in the Visegrad Group (V4) countries. Multiple regression analyses are used to establish links between accounting attributes on the sample of 64 listed firms for the time period between 2005 and 2017. This study shows that relevance is a more dominant accounting attribute than reliability. Companies listed in the V4 markets share this feature with companies listed in more mature markets. However, neither trade-off between relevance and reliability nor any trend in these accounting attributes was detected. The lack of these dynamics may be explained by different financial statements' information needs of users in the V4 countries compared to users operating in more mature markets.
\end{abstract}

Key words: Visegrad group; International Financial Reporting Standards; Earnings Usefulness; Relevance in accounting; Reliability in accounting.

JEL classification: M41.

\section{Introduction}

Relevance and reliability are important characteristics of accounting information. Relevant information could be defined as information about the firm's future economic prospect - that is, its dividends, cash flows, and profitability. Reliable information, on the other hand, is information that financial users can trust. Both these characteristics have more rigorous accounting definitions which will be discussed in Section 2. Accounting theoretician William R. Scott (2015) presents a theoretical framework underscoring the role of relevance and reliability

Libor Závodný; Prague University of Economics and Business, Faculty of Finance and Accounting, Department of Financial Accounting and Auditing, W. Churchill Sq. 4, 13067 Prague 3, Czech Republic, <libor.zavodny@vse.cz>, ORCID: 0000-0003-1470-3180.

The paper has been prepared within the research project "The determinants of accounting quality in emerging and transitioning economies" (OP RDE IGA/A, CZ.02.2.69/0.0/0.0/19_073/0016936, project no. 15/2021). 


\section{Závodný, L.: Relevance Versus Reliability Trade-off in Financial Reporting among Companies Listed at Visegrad Group Stock Exchanges.}

in accounting. Under the ideal conditions of future cash flows known with certainty and given interest rates in the economy, it is possible to prepare completely relevant and reliable financial statements. The process of arbitrage ensures that the market value of an asset equals the present value of its future cash flows. However, under realistic conditions, i.e. uncertainty, the expected and realised cash flows need no longer be the same and a trade-off between relevance and reliability in accounting information arises.

The research tradition of studying earnings usefulness in relation to capital markets began with the study of Ball and Brown (1968). Empirical research into accounting relevance and reliability was started by Kim and Kross (2005), which is discussed in detail in Section 3. However, this literature has centred on developed markets, with little attention given to emerging markets. The significance of accounting information in developed countries may be different than in less developed countries (Graham et al., 2000), which have different economic, social, and cultural characteristics. Empirical research on the role of accounting information in emerging markets can investigate these issues and enhance our understanding of this role. To date, however, very little research has investigated the particular importance of accounting information to emerging markets.

This study seeks to redress this gap by examining the Visegrad Group (V4) emerging markets and their value relevance issues. This is done in the context of the firms traded on the stock markets of the Visegrad group countries (V4) i.e. Czech Republic, Poland, Hungary, and Slovakia. This region is a distinct part of the Central and Eastern Europe area (CEE). As summarised by Procházka (2015), in CEE there are less developed capital markets (lower number of listed companies, lower market cap per GDP); weaker macroeconomic indicators (lower GDP per capita); and different microeconomic indicators (e.g. higher number of companies controlled by a foreign parent). Besides, a compound indicator Global Competition Index (GCI) measuring the quality of economic social and political environment ranks the CEE counties below the old EU member states in most measured categories (GCI, 2018).

\section{Background and Literature Review}

\subsection{Theoretical background}

Accounting information possessing usefulness for decision-making shall have certain qualitative characteristics. For example, the Conceptual Framework to International Financial Reporting Standards mentions relevance and faithful representation as fundamental characteristics. Comparability, verifiability, 
timeliness and understandability are listed as enhancing characteristics. The Conceptual Framework defines relevance as:

"Relevant financial information is capable of making a difference in the decisions made by users. Financial information is capable of making a difference in decisions if it has predictive value, confirmatory value, or both. The predictive value and confirmatory value of financial information are interrelated." (Conceptual Framework for Financial Reporting, 2018).

On the other hand, reliability is not viewed as fundamental or enhancing characteristic. Rather, it is expressed through a tolerable level of measurement uncertainty forming a part of the second fundamental characteristic, i.e. faithful representation (Pelger, 2019).

The debate about the trade-off between relevance and reliability most commonly addresses the measurement issue, in particular when deciding on the pros and cons of historical cost accounting vs. current value accounting. Historical cost accounting is relatively reliable since the cost of an asset or liability to a firm is usually a verifiable number that is less subject to errors of estimation bias, present in current value calculations. However, historical costs may be low in relevance. While cost may equal current value at the date of acquisition, the equality will be lost as current values change over time. Consequently, the relevance of current value accounting generally exceeds that of historical cost. But the need for estimates when conditions are not ideal opens current value accounting up to problems of reliability (Scott, 2015).

The Conceptual Framework does not specifically state that relevance and reliability have to be traded off; however, it notes that:

"Information must be both relevant and faithfully represented if it is to be useful... First, identify an economic phenomenon that has the potential to be useful to users of the reporting entity's financial situation. Second, identify the type of information about that phenomenon that would be most relevant if it is available and can be faithfully represented. Third, determine whether that information is available and can be faithfully represented. If so, the process of satisfying the fundamental qualitative characteristics ends at that point. If not, the process is repeated with the next most relevant information." (Conceptual Framework for Financial Reporting, 2018).

Hence, a relevance/reliability trade-off is implicit in the Framework since repeating the process with "the next most relevant type of information" in order 


\section{Závodný, L.: Relevance Versus Reliability Trade-off in Financial Reporting among Companies Listed at Visegrad Group Stock Exchanges.}

to attain the hurdle level of reliability clearly indicates that if reliability increases, relevance must decrease ${ }^{1}$.

\subsection{IFRS adoption and its indirect effects on relevance and reliability}

As this paper will focus on the V4 listed firms, for which IFRS became mandatory as of 2005 following the EU Regulation No. 1606/2002, we firstly review literature investigating the effects of IFRS adoption and how the replacement of local GAAP by internationally recognised standards contributed to the perception of relevance and/or reliability of information presented in financial statements. Wang and Yu (2014) investigated whether the adoption of superior accounting standards impacts share prices. In a sample of companies from 44 countries that applied either IFRS or US GAAP, the authors found that the information contained in financial statements prepared according to the newly adopted standards is reflected in the share prices faster than before. These findings, however, appear only in countries with developed investor protection regulations, effective legal system, and functioning enforcement mechanisms. Devalle et al. (2010) found an increased influence of earnings prepared according to IFRS on the share prices in three out of five Western European stock exchanges. Investors anticipated higher quality information as a result of information asymmetry reduction and improved comparability of financial statements post the IFRS implementation. Again, the positive feedback did not appear if the perceived effectiveness of enforcing mechanisms in the given country was weak. Armstrong at al. (2010) confirmed the crucial role of institutional framework featured in other studies investigating stock market efficiency following the IFRS implementation. Generally, liquidity in such markets increased and cost of capital decreased on the condition that the enforcement mechanism was perceived to be efficient (Daske et al., 2008; Lee at al., 2008; Li, 2010; Daske et al., 2013; Christensen et al., 2013). Similarly, investor activity into the stock exchange markets which implemented IFRS increased more if enforcement was perceived to be efficient (DeFond et al., 2011; Brüggemann at al., 2012; Florou and Pope, 2012; Beneish et al., 2012).

In light of the above findings, the question is in what way IFRS implementation affected the stock exchanges of V4 and CEE. It seems that IFRS implementation did not result in market efficiency improvements. Related to CEE countries, two studies which more directly devote to this issue were conducted in Poland.

\footnotetext{
${ }^{1}$ Relevance reliability trade-off is a dominant feature of financial statements from the investors' point of view, held in this paper. Opposed to this view, financial statement may be used as the basis for contractual purposes (e.g. managerial contracts, loan contracts). Dominant feature of the contractual view would be the trade-off between sensitivity and precision; however, this view is not taken in this paper.
} 
In their capital market research, Dobija and Klimzak (2010) covered the time period between 1994 and 2008 within which the adoption of IFRS occurred (in 2005). The authors confirmed that reported earnings were reflected in the share price, however, the strength of the association had not changed over the time span of the researched, indicating no impact of IFRS adoption on the market efficiency. Klimzak (2010) replicated the methodology of Armstrong et al. (2010), whose research was mentioned above, on the Polish stock exchange market and concluded that there was no noticeable investor reaction to the IFRS implementation.

\subsection{Evidence on relevance and reliability}

The research into relevance and reliability is closely linked to the research of earnings' usefulness which examines the association between earnings and share returns. The study field of "earnings usefulness" has been pursued by many researchers, e.g. Lev (1989), Amir and Lev (1996), Lev and Zarowin (1999), Brown et al. (1999), and Collins at al. (1997). Generally, there are findings in these papers indicating that the strength of the association between accounting earnings and share returns is deteriorating over time. Some more recent studies confirm the earnings usefulness deterioration (Lev, 2018), (Lev and $\mathrm{Gu}, 2016$ ). On a similar note, Khan et al. (2017) found that $75 \%$ of the 138 standards issued by FASB from its inception (1974) had no impact on share prices of the firms implementing the standards.

Several studies concerned the question as to what accounting attributes ensure earnings usefulness. Collins at al. (1997) studied relations between earnings usefulness and accounting methods used. A pivotal study examining the relations between accounting relevance and earning usefulness aspects of financial statements presented Kim and Kross (2005). They empirically supported the claim that financial statements allow for a better prediction of future cash flows compared to current cash flows themselves, with an increasing trend over the investigated period of time (i.e. increasing relevance of financial statements). However, besides that, they confirmed a declining role of earnings as the factor explaining share prices, which they calculated to be $5.7 \%$ on a large sample of the US firms covering the time period 1992-2000 (i.e. decreasing earning usefulness). In their paper, they reported a "puzzling" conclusion, despite increasing relevance of financial statements, usefulness of earnings decreases. This paper was followed by Bandyopadhyay, Chen, Huang, and Jha (2010) who tested a large sample of American companies over the period of 33 years from 1973 to 2005. Besides relevance, they also introduced the factor of reliability and examined how both these factors contribute to earnings' usefulness. They confirmed that the relevance of net income increased over their sample 


\section{Závodný, L.: Relevance Versus Reliability Trade-off in Financial Reporting among Companies} Listed at Visegrad Group Stock Exchanges.

period (1973-2005) and reliability decreased at the same time, clearly implying the trade-off. They expanded the argument by proving that conservatism in accounting increases relevance while at the same time decreases reliability. Through this evidence, they also provided the answer to the "puzzling" conclusion of Kim and Kross (2005). According to Bandyopadhyay et al., usefulness of earnings for explaining share prices over book values is positively related to reliability though not to relevance. This paper aims to derive a similar hypothesis in the context of the Visegrad Group countries.

This study relates to the value relevance literature under the umbrella of the four constructs advanced by Francis and Schipper (1999). They state: "financial information is value relevant if it contains the variables used in a valuation model or assists in predicting those variables." They indicate that value relevance could be measured by the ability of earnings to predict future cash flows.

As far as reliability is concerned, Richardson et al. (2005) argue that the definition of reliability as "the quality of information that assures that information is free from error and bias and faithfully represents what it purports to represent" provides the link between accrual reliability and earnings persistence. Earnings persistence is suggested as a proxy for reliability based on the argument that measurement error in accounting accruals imparts potential error in the earnings measurement process and thereby lowers the correlation between current and future earnings (earnings persistence). Similarly, Kirschenheiter (1997) suggests that reliability is linked to the estimation process in accounting measurements and it is measured by the "precision of an estimate". Based on the literature reviewed above, we propose the following two hypotheses.

H1: The relation between the share price and earnings is positively related to the ability of current earnings to predict future cash flow (relevance).

H2: The relation between the share price and earnings is positively related to the ability of current earnings to predict future earnings (reliability)

\section{Research Design}

\subsection{Sample data}

The observations are based on annual financial statements provided by the THOMSON REUTERS business database. Share price quotations are taken annually at the end of April when all companies release their financial statements.

\footnotetext{
2 The definition presented by Richardson at al. (2005) is extracted from the US GAAP standard SFAC No. 2 (paragraph 57). It is assumed that its meaning equals that of the reliability definition by IFRS Conceptual Framework, as indicated in Section 2.
} 
Each market index contains a different number of companies. There are 30 firms in the Polish WIG 30, 12 firms in the Czech PX, 15 firms in the Hungarian Budapest SE, and 7 firms in the Slovakian SAX. The number of observations in each market corresponds to its number of firms. The largest number of observations, 1,368, corresponded with the Polish index WIG 30. Observations related to the other indexes numbered lower; 504 for the PX, 732 for the Budapest SE, and 352 for the SAX. Company observations are excluded if the required variables are not available. Moreover, outliers which were more than four standard deviations from the mean and would unduly distort the analysis were also excluded. Such instances consisted of 12 observations in total.

\subsection{Methodology}

The methodology rests on the modified approaches developed by Bandyopadhyay, Chen, Huang, and Jha (2010). To test the hypothesis univariate and multivariate OLS linear regressions are run on the variables described below. In order to obtain a time series of all the tested variables, 4-year moving averages were considered in regression calculations. Hence, as a consequence of the calculations of the moving average, the final time series was restricted to the period 20072015. The main dependent and explanatory variables are defined as:

\section{Primary variables}

E earnings (defined as net income)

CFO cash flows from operations

PRC price per share

EPS earnings per share

BSV book value per share (equity per share)

The price per share is defined as an annual share price and not adjusted for a possible ex-dividend factor. Share price quotations are taken annually at the end of April by when all companies publicise their financial statements.

\section{Secondary variables}

FE

FCFO incremental contribution of earnings in explaining future cash

EU flows (relevance)

earnings utility 


\section{Measuring future cash flow predictability (relevance)}

One-year-ahead cash flows on current operating cash flows and current earnings are regressed by each firm:

$$
C F O_{t+1}=c+\beta 1 * C F O t+\beta 2 * E t+\varepsilon t,
$$

For each firm, a time series regression is run to estimate Eq. 1. In turn, Eq. 1 is rerun by including only $\mathrm{CFO}$ as the independent variable, i.e.:

$$
C F O_{t+1}=c+\beta 1 * C F O_{t}+\varepsilon t
$$

Each equation produces $\mathrm{R}^{2}$. The difference between $\mathrm{R}^{2}$ of Eq. 2 and $\mathrm{R}^{2}$ of Eq. 1 allows to determine the future cash flows predictability (FCFO). FCFO represents the incremental contribution of current earnings in explaining future cash flows. FCFO could then be used as the primary measure of relevance as stated by Bandyopadhyay, Chen, Huang, and Jha (2010).

$$
F C F O=R_{1}^{2}-R_{2}^{2}
$$

\section{Measuring future earnings predictability (reliability)}

The measure of the ability of current earnings to predict future earnings (FE) is computed in a manner similar to the ability of the current earnings to predict future cash flows. The following earnings forecast models are estimated:

$$
E_{t+1}=c+\beta 1 * C F O_{t}+\beta 2 * E_{t}+\varepsilon t,
$$

and

$$
E_{t+1}=c+\beta 1 * C F O t+\varepsilon t,
$$

Consistent with the measurement of cash flow predictability (FCFO), the difference between the explanatory power $\mathrm{R}^{2}$ of Eq. 5 in each period and that of Eq. 4 represents the incremental contribution of current earning explaining future earnings. FE is then used as the primary measure of reliability again as proposed by Bandyopadhyay, Chen, Huang, and Jha (2010). 


$$
F E=R_{4}^{2}-R_{5}^{2}
$$

\section{Measuring price-earnings relation (earnings usefulness)}

Consistent with Collins at al. (1997), the measure of earnings usefulness is estimated from the following equations:

$$
P R C_{t}=c+\beta 1 * B V S_{t}+\beta_{2} * E P S_{t}+\varepsilon t,
$$

and

$$
P R C_{t}=c+\beta 1 * B V S_{t}+\varepsilon t,
$$

Similar to the above-mentioned incremental $\mathrm{R}^{2}$ computation, earnings usefulness $(\mathrm{EU})$ is measured as the above difference between the $\mathrm{R}^{2}$ of Eq. 7 and the $\mathrm{R}^{2}$ of Eq. 8 .

$$
E U=R_{7}^{2}-R_{8}^{2},
$$

Results in terms of $\mathrm{R}^{2}$ produced by Eq. 3, 6, and 9, representing FCFO, FE, and EU, respectively, are utilised in the following regression, which generates the degree at which relevance and reliability contribute to earnings usefulness.

$$
E U_{t}=c+\beta 1 * F C F O_{t}+\beta_{2} * F E_{t}+\varepsilon t
$$

\section{Model details}

The related previous research is typically conducted at the aggregate market or industry level. This aggregate approach allows for a limited control of the heterogeneity of the firm-specific characteristics. In contrast, this research conducts the analysis at the individual firm level and the market aggregate is reached through arithmetic averages containing all the firm is the sample.

Test calculations showed that introducing more control variables into the regression equation led to augmentation of the variance inflation factor, increasing the standard error of the model. Therefore, only two variables are taken into account.

To assess the quality of the association, considered is the confidence level of $95 \%$. Results that fall below the 95\% confidence level (P-value is over 0.05) are shown but not taken into consideration. Results of the tests of normality, heteroscedasticity, and autocorrelation diagnostics tests are presented in Appendix 1. Diagnostics tests of the models used were performed on the aggregate market 
Závodný, L.: Relevance Versus Reliability Trade-off in Financial Reporting among Companies Listed at Visegrad Group Stock Exchanges.

data indicating that utilisation of OLS linear regression is appropriate and the conditions for inference are met.

\section{Results and Discussion}

Tables 1 through 4 represent the numerical results of Eq. 3, 6, and 9 for each of the reviewed markets. There are patterns of earnings' attributes that are observed in every examined market. The measure of relevance (FCFO) attains a higher $\mathrm{R} 2$ percentage in terms of its mean than the measure of reliability (FE) and the same can be said for median (except for the PX) indicating that prominence of relevance is generally higher in financial statements than reliability over the period under review. The standard deviation of relevance is also higher than that of reliability (except for the Budapest SE) which reflects the more volatile nature related to current value accounting measurement over that of historical cost accounting.

None of the earnings attributes displays significantly growing or diminishing trend in any market. This fact conflicts with the findings of Bandyopadhyay, Chen, Huang, and Jha (2010) who reported diminishing trends in EU and FE, while they found a growing trend in FCFO.

Tab. 1 Trends in earnings attributes in the PX, $\mathbf{R}^{2}$

\begin{tabular}{lccrrrrrrrrrr}
\hline Year & 07 & 08 & 09 & 10 & 11 & 12 & 13 & 14 & 15 & Mean & Med & SD \\
\hline FCFO (\%) & 40.0 & 53.4 & 51.8 & 58.2 & 33.5 & 23.1 & 20.9 & 25.5 & 30.7 & $\mathbf{3 7 . 4}$ & $\mathbf{3 3 . 5}$ & $\mathbf{1 4 . 1}$ \\
FE (\%) & 29.3 & 31.5 & 40.2 & 43.0 & 20.6 & 29.4 & 39.7 & 35.1 & 37.5 & $\mathbf{3 4 . 0}$ & $\mathbf{3 5 . 1}$ & $\mathbf{7 . 0}$ \\
EU (\%) & 45.1 & 24.1 & 39.0 & 22.2 & 27.9 & 42.0 & 25.8 & 34.2 & 36.2 & $\mathbf{3 3 . 0}$ & $\mathbf{3 4 . 2}$ & $\mathbf{8 . 3}$ \\
\hline
\end{tabular}

Source: authorial computation.

Tab. 2 Trends in earnings attributes in the WIG 30, $\mathbf{R}^{2}$

\begin{tabular}{lcccccccccccc}
\hline Year & 07 & 08 & 09 & 10 & 11 & 12 & 13 & 14 & 15 & Mean & Med & SD \\
\hline FCFO (\%) & 32.8 & 35.5 & 38.0 & 59.0 & 38.2 & 40.4 & 36.3 & 26.0 & 41.7 & $\mathbf{3 8 . 7}$ & $\mathbf{3 8 . 0}$ & $\mathbf{8 . 9}$ \\
FE (\%) & 30.5 & 22.5 & 34.2 & 38.9 & 35.6 & 38.4 & 27.8 & 30.7 & 30.9 & $\mathbf{3 2 . 2}$ & $\mathbf{3 0 . 9}$ & $\mathbf{5 . 2}$ \\
EU (\%) & 50.2 & 34.2 & 29.5 & 29.4 & 18.7 & 26.3 & 31.6 & 33.7 & 35.2 & $\mathbf{3 2 . 1}$ & $\mathbf{3 1 . 6}$ & $\mathbf{8 . 5}$ \\
\hline
\end{tabular}

Source: authorial computation.

Tab. 3 Trends in earnings attributes in the Budapest SE, $\mathbf{R}^{2}$

\begin{tabular}{lrrrrrrrrrrrr}
\hline Year & 07 & 08 & 09 & 10 & 11 & 12 & 13 & 14 & 15 & Mean & Med & SD \\
\hline FCFO (\%) & 30.6 & 35.2 & 49.2 & 28.5 & 44.5 & 49.2 & 27.4 & 24.4 & 27.0 & $\mathbf{3 5 . 1}$ & $\mathbf{3 0 . 6}$ & $\mathbf{9 . 9}$ \\
FE (\%) & 21.9 & 13.7 & 24.2 & 29.4 & 12.1 & 33.6 & 26.4 & 17.3 & 45.2 & $\mathbf{2 4 . 9}$ & $\mathbf{2 4 . 2}$ & $\mathbf{1 0 . 4}$ \\
EU (\%) & 44.4 & 29.3 & 39.0 & 23.7 & 35.1 & 29.7 & 50.9 & 23.6 & 40.3 & $\mathbf{3 5 . 1}$ & $\mathbf{3 5 . 1}$ & $\mathbf{9 . 4}$ \\
\hline
\end{tabular}

Source: authorial computation. 
Tab. 4 Trends in earnings attributes in the SAX, $\mathbf{R}^{2}$

\begin{tabular}{lcccccccccccc}
\hline Year & 07 & 08 & 09 & 10 & 11 & 12 & 13 & 14 & 15 & Mean & Med & SD \\
\hline FCFO (\%) & 70.1 & 56.7 & 54.1 & 45.9 & 32.2 & 31.3 & 43.3 & 44.4 & 18.8 & $\mathbf{4 4 . 1}$ & $\mathbf{4 4 . 4}$ & $\mathbf{1 5 . 4}$ \\
FE (\%) & 55.0 & 20.0 & 38.1 & 43.3 & 30.9 & 43.0 & 36.6 & 21.1 & 14.1 & $\mathbf{3 3 . 6}$ & $\mathbf{3 6 . 6}$ & $\mathbf{1 3 . 2}$ \\
EU (\%) & 27.6 & 29.0 & 19.6 & 21.1 & 23.0 & 14.3 & 22.4 & 36.9 & 37.9 & $\mathbf{2 5 . 8}$ & $\mathbf{2 3 . 0}$ & $\mathbf{7 . 9}$ \\
\hline
\end{tabular}

Source: authorial computation.

Table 5 shows the results of Eq. 9 for each market in an industrial cross-section. When dividing the companies in each market between financial and non-financial sectors, no additional findings were made except that earnings' usefulness (EU) was higher among financial companies compared to non-financial companies in every market. As per Dechow (1994), earnings' usefulness is contingent upon the magnitude of accruals created. The larger the magnitude of accruals the company creates, the more significant the association between share price and earnings relative to the association between share price and cash flows (Dechow, 1994). Therefore, it could be hypothesised that financial sector companies create a higher magnitude of accruals. To confirm such a hypothesis, a follow-up research is required.

Tab. 5 Regression analysis by sectors, $\mathbf{R}^{2}$

\begin{tabular}{lll}
\hline Market & Sector & EU \\
\hline PX & Financial & $35.27 \%$ \\
& Non-financial & $27.82 \%$ \\
WIG 30 & Financial & $36.05 \%$ \\
& Non-financial & $30.26 \%$ \\
Budapest SE & Financial & $35.62 \%$ \\
& Non-financial & $35.54 \%$ \\
SAX & Financial & $26.19 \%$ \\
& Non-financial & $25.14 \%$ \\
\hline
\end{tabular}

Source: authorial computation.

Resulting P-values in Table 6 indicate a statistical confidence level below 95\% in all markets. Obtaining results on a low confidence level leads to the interpretation that there is no statistically significant association between FE and FCFO on one side and EU on the other side. A low confidence level is measured in relation to the results in Table 7 as well. Therefore, no statistically significant indication of correlation between FE and FCFO can be stated. 
Závodný, L.: Relevance Versus Reliability Trade-off in Financial Reporting among Companies Listed at Visegrad Group Stock Exchanges.

Tab. 6 Multivariate regression analysis; EU, FE, FCFO

\begin{tabular}{lccccc}
\hline Market & $\boldsymbol{\beta}_{1}(\mathbf{F E})$ & $\boldsymbol{\beta}_{2}(\mathbf{F C F O})$ & $\mathbf{R}^{\mathbf{2}}$ & F-statistics & P-value \\
\hline PX & -0.16 & -0.15 & $10.42 \%$ & 0.34 & 0.71 \\
WIG 30 & -0.66 & -0.06 & $20.59 \%$ & 0.77 & 0.50 \\
Budapest SE & 0.17 & -0.01 & $3.83 \%$ & 0.11 & 0.88 \\
SAX & -0.50 & 0.17 & $54.22 \%$ & 3.55 & 0.09 \\
\hline
\end{tabular}

Source: authorial computation.

Tab. 7 Relevance (FCFO) / Reliability (FE) correlation

\begin{tabular}{llll}
\hline Market & R & F-statistics & P-value \\
\hline PX & 0.26 & 0.53 & 0.48 \\
WIG 30 & 0.56 & 3.22 & 0.11 \\
Budapest SE & 0.14 & 0.14 & 0.71 \\
SAX & 0.52 & 2.60 & 0.15
\end{tabular}

Source: authorial computation.

\section{Conclusions}

No evidence was found in support of $\mathrm{H} 1$ and $\mathrm{H} 2$, thus $\mathrm{H} 1$ and $\mathrm{H} 2$ are neither confirmed nor refuted ${ }^{3}$. The markets do not seem to "fine-tune" their response to take into account the reliability and relevance characteristics of earnings. Secondly, the trade-off between relevance and reliability was not identified. Hence, relevance vs. reliability trade-off does not seem to be the defining factor of accounting earnings quality in the V4 countries.

As this research directly follows Bandyopadhyay et al. (2010), we can compare the results of both studies in more detail. Bandyopadhyay at al. (2010) concluded that relevance is more prominent accounting feature than reliability and while relevance is on the rise, reliability decreases. The findings of Bandyopadhyay at al. (2010) were not fully replicated in the V4 markets. No trends were found in either reliability or relevance accounting characteristics. Although no trends were detected, this research shows that accounting relevance attains higher significance than reliability in all the examined markets as measured by both the mean and median R2 for the period under review. Such findings correspond with Bandyopadhyay at al. (2010). These findings may be driven by the fact that an accounting system prioritizing current values over historic accounting

\footnotetext{
${ }^{3}$ Following the established scientific principle: "Absence of evidence is not evidence of absence".
} 
is applied in both the V4 countries and mature markets and also that this system follows IFRS.

Thus, we can state that in terms of the general accounting focus, relevance is the more prominent characteristic compared to reliability both in the V4 markets and in more mature markets. However, regarding more subtle features related to relevance reliability trade-off and trends of these attributes, the V4 markets have not yet developed the same dynamics as mature markets.

That may be explained by different information preferences of the accounting information users. It could be an indication that contracting purposes of accounting in the V4 counties ultimately prevail over the investor decisionmaking purposes. Such an indication is in line with Procházka (2015) who expects a contractual role of accounting to dominate over the investor's role in the V4 countries due to reduced dependence of the V4 companies on the local stock market exchanges for their financing and increased dependence on financing from the foreign parent companies. If this is the case, then it is not relevance versus reliability trade-off which should be expected as the driving factor of accounting earnings quality, but rather the trade-off between precision and sensitivity of accounting information, which is crucial from the contractual perspective (Scott, 2015). Possible follow-up research could then focus on examining the development of these earnings attributes. Alternatively, it could be a result of less efficient IFRS implementation in the CEE region as indicated by studies listed in Section 2.

The conclusions drawn are subject to an unavoidably small sample size as the major indexes contain a relatively small number of companies. In addition, due to data availability, the study period was limited to 12 years in investigating the earnings attributes of accounting information. Therefore, the question remains to what extent is accounting information important and powerful for participants in making investment decisions. Informal information channels may deliver credible and useful competing information available to market participants. An important implication of this finding is that the V4 countries need to develop their accounting information environment further to become more efficient in offering a free exchange of information about companies listed on the local stock exchanges. 
Závodný, L.: Relevance Versus Reliability Trade-off in Financial Reporting among Companies Listed at Visegrad Group Stock Exchanges.

\section{References}

Amir, E., Lev, B., 1996. Value-Relevance of Nonfinancial Information: The Wireless Communications Industry. Journal of Accounting and Economics 22 (1-3), pp 3-30. ISSN: 0165-4101.

Armstrong, C., Barth M. E., Jagolinzer, A. D., Riedl, E. J., 2010. Market reaction to the Adoption of IFRS in Europe. The Accounting Review, vol. 85, no. 1, pp 3161. ISSN: 00014826.

Ball, R., Brown, P., 1968. An empirical evaluation of accounting income numbers. Journal of Accounting Research, 6(autumn), pp 169-178. ISSN: 1475-679X.

Bandyopadhyay, S., Chen, C., Huang, A., Jha, R., 2010. Accounting Conservatism and the Temporal Trends in Current Earnings' Ability to Predict Future Cash Flows versus Future Earnings: Evidence on the Trade-off between Relevance and Reliability. Contemporary Accounting Research (Summer 2010), pp 413-460. ISSN:1911-3846.

Beneish, M. D., Miller, B. P., Yohn, T. L., 2012. The impact of Financial Reporting on Equity versus Debt Markets: Macroeconomic Evidence from mandatory IFRS Adoption. SSRN Electronic Journal. ISSN: 15565068.

Brown, S., Lo, K., Lys, T., 1999. Use of R-squared in accounting research: measuring changes in value relevance over the last four decades. Journal of Accounting and Economics, vol. 28, pp 83-155. ISSN: 0165-4101.

Brüggemann, U., Daske, H., Homburg, C., Pope, P. F., 2012. How do Individual Investors react to Global IFRS Adoption? SSRN Electronic Journal. ISSN: 15565068. Available from: <ssrn.com/abstract=1458944>. [17 September 2020].

Christensen, H. B., Hail, L., Leuz, C., 2013. Mandatory IFRS Reporting and Changes in Enforcement. Journal of Accounting and Economics, vol. 56, no. 2-3, pp 147-177. ISSN: 01654101.

Clikeman, P., M., 2013. Called to Account. Routledge. ISBN: 978-0-415-63024-5

Collins, D. W., Maydew, E. L., Weiss, I. F., 1997. Changes in the value relevance of earnings and book values over the past forty years. Journal of Accounting and Economics, vol. 24, pp 39-67. ISSN: 0165-4101.

Conceptual Framework for Financial reporting, 2018. Available from: <ifrs.org>. [17 September 2020].

Daske, H., Hail, L., Leuz, C., Verdi, R., 2008. Mandatory IFRS Reporting around the World: Early Evidence on the Economic Consequences. Journal of Accounting Research, vol. 46, no. 5, pp 1085-1142. ISSN: 00221082.

Daske, H., Hail, L., Leuz, C., Verdi, R., 2013. Adopting a Label: Heterogeneity in the Economic Consequences Around IAS/IFRS Adoptions. Journal of Accounting Research, vol. 51, no. 3, pp 495-547. ISSN 00218456. 
Dechow, P., M., 1994. Accounting earnings and cash flows as measures of firm performance: The role of accounting accruals. Journal of Accounting and Economics (July 1994), pp 3-42. ISSN 01654101.

DeFond, M., Hu X., Hung, M., Li, S., 2011. The Impact of Mandatory IFRS Adoption on Foreign Mutual Fund Ownership: The role of Comparability. Journal of Accounting and Economics, vol. 51, no. 3, pp 240-258. ISSN: 01654101.

Devalle, A., Onali, E., Magarini, R., 2010. Assessing the Value Relevance of Accounting data after the Introduction of IFRS in Europe. Journal of International Financial Management \& Accounting, vol. 21, no. 2, pp 85-119. ISSN: 09541314.

Dobija, D., Klimczak, K. M., 2010. Development of Accounting in Poland: Market Efficiency and the Value Relevance of Reported Earnings. International Journal of Accounting, 45(3): 356-374. ISSN 1094-4060.

Florou, A., Pope, P., 2012. Mandatory IFRS Adoption and Institutional Investment Decisions. The Accounting Review, vol. 30, no. 6, pp 1993-2025. ISSN: 08826110.

Francis, J., Schipper, K., 1999. Have financial statements lost their relevance? Journal of Accounting Research, vol. 37, pp 319-352. ISSN: 0021-8456.

Global Competitiveness Index, 2018. Available from: <weforum.org/reports/theglobal-competitiveness-report-2017-2018>. [17 September 2020].

Graham, R., King, R., Bailes, J., 2000. The value relevance of accounting information during a financial crisis: Thailand and the 1997 decline in the value of the baht. Journal of International Financial Management \& Accounting, vol. 11(2), pp. 84. ISSN: 1467-646X.

Khan, U., Li, B., Rajgopal, S., Venkatachalam, M., 2017. Do the FASB's standards add shareholder value? Columbia School of Business.

Kim, M., W. Kross, W., 2005. The Ability of Earnings to Predict Future Operating Cash Flows Has Been Increasing - Not Decreasing. Journal of Accounting Research (December 2005), pp 753-780. ISSN: 0021-8456.

Kirschenheiter, M, 1997. Information Quality and Correlated Signals. Journal of Accounting Research, vol. 35(1), pp. 43-59. ISSN: 0021-8456.

Klimzak, K. M., 2011. Market reaction to Mandatory IFRS Adoption: Evidence from Poland. Accounting \& Management Information Systems, vol. 10, no. 2, pp. 228-248. ISSN: 18438105.

Li, S., 2010. Does Mandatory Adoption of International Financial Reporting Standards in the European Union reduce the Cost of Equity Capital? The Accounting Review, vol 85, nr. 2, pp. 607-636. ISSN: 00014826. 
Lee, E., Walker, M., Christensen, H. B., 2008. Mandating IFRS: Its Impact on the Cost of Equity Capital in Europe. The Association of Chartered Certified Accountants. ISBN 9781859084458.

Lev, B., 2018. The deteriorating usefulness of financial report information and how to reverse it. Accounting and Business Research, 48:5, pp 465-493. ISSN 2159-4260.

Lev, B., 1989. On the Usefulness of Earnings and Earnings Research: Lessons and Directions from Two Decades of Empirical Research. Journal of Accounting Research vol 27, no. 3, pp 153-192. ISSN: 0021-8456.

Lev, B., Gu, F., 2016. The End of Accounting and the Path Forward for Investors and Managers. Hoboken, NJ: Wiley. ISBN: 978-1-119-19109-4.

Lev, B., Zarowin, P., 1999. The Boundaries of Financial Reporting and How to Extend Them. Journal of Accounting Research (Autumn 1999), 99. 353-385. ISSN: 0021-8456.

Pelger, C., 2019. The Return of Stewardship, Reliability, and Prudence A Commentary on the IASB's New Conceptual Framework. Accounting in Europe, vol. 16. ISSN: 1744-9480.

Procházka, D., 2015. Ekonomické dopady implementace IFRS v Evropě. Oeconomica. ISBN 978-80-245-2097-1.

Richardson, S. A., Sloan, R. G., Soliman, M. T., I. Tuna, 2005. Accrual Reliability, Earnings Persistence, and Stock Prices. Journal of Accounting and Economics, vol. 39(3), pp. 437-485. ISSN: 0165-4101.

Scott R. W., 2015. Financial Accounting Theory 7th edition. Pearson. ISBN 9780-13-298466-9.

Wang, J. W., Yu, W. W., 2014. The Information Content of Stock Prices, Legal Environments, and Accounting Standards: International Evidence. European Accounting Review [online]. ISSN: 09638180. Available from: <tandf online.com/doi/abs/10.1080/09638180.2014.977802>. [17 September 2020]. 


\section{Appendix 1}

Tab. 8 Diagnostics tests

\begin{tabular}{|c|c|c|c|}
\hline $\begin{array}{l}\text { Equation nr./ } \\
\text { Market }\end{array}$ & $\begin{array}{l}\text { Normality test } \\
\text { (Pagan-Godfrey) } \\
\text { H0: Normal disc. } \\
\text { H1: Not-normal disc. } \\
\text { Prob. }\end{array}$ & $\begin{array}{l}\text { Autocorrelation test } \\
\text { (Breusch-Godfrey) } \\
\text { H0: No serial corr. } \\
\text { H1: Serial corr. } \\
\text { Prob. (Chi-Square) }\end{array}$ & $\begin{array}{r}\text { Heteroskedasticity test } \\
\text { (Breusch-Pagan-Godfrey) } \\
\text { H0: Homoskedasticity } \\
\text { H1: Heteroskedasticity } \\
\text { Prob. (Chi-Square) }\end{array}$ \\
\hline \multicolumn{4}{|l|}{ Equation 1} \\
\hline PX & 0.57 & 0.05 & 0.39 \\
\hline WIG 30 & 0.70 & 0.11 & 0.97 \\
\hline Budapest SE & 0.74 & 0.46 & 0.75 \\
\hline SAX & 0.07 & 0.14 & 0.71 \\
\hline \multicolumn{4}{|l|}{ Equation 2} \\
\hline PX & 0.58 & 0.07 & 0.72 \\
\hline WIG 30 & 0.68 & 0.14 & 0.76 \\
\hline Budapest SE & 0.76 & 0.59 & 0.55 \\
\hline SAX & 0.06 & 0.45 & 0.56 \\
\hline \multicolumn{4}{|l|}{ Equation 4} \\
\hline PX & 0.18 & 0.82 & 0.76 \\
\hline WIG 30 & 0.88 & 0.05 & 0.93 \\
\hline Budapest SE & 0.71 & 0.13 & 0.44 \\
\hline SAX & 0.06 & 0.41 & 0.71 \\
\hline \multicolumn{4}{|l|}{ Equation 5} \\
\hline PX & 0.25 & 0.57 & 0.30 \\
\hline WIG 30 & 0.92 & 0.05 & 0.64 \\
\hline Budapest SE & 0.82 & 0.19 & 0.69 \\
\hline SAX & 0.77 & 0.89 & 0.54 \\
\hline \multicolumn{4}{|l|}{ Equation 7} \\
\hline PX & 0.58 & 0.36 & 0.71 \\
\hline WIG 30 & 0.66 & 0.71 & 0.71 \\
\hline Budapest SE & 0.45 & 0.47 & 0.57 \\
\hline SAX & 0.59 & 0.53 & 0.62 \\
\hline \multicolumn{4}{|l|}{ Equation 8} \\
\hline PX & 0.98 & 0.88 & 0.55 \\
\hline WIG 30 & 0.63 & 0.84 & 0.62 \\
\hline Budapest SE & 0.91 & 0.48 & 0.43 \\
\hline SAX & 0.68 & 0.16 & 0.99 \\
\hline \multicolumn{4}{|l|}{ Equation 10} \\
\hline $\mathrm{PX}$ & NA & NA & NA \\
\hline WIG 30 & NA & NA & NA \\
\hline Budapest SE & NA & NA & NA \\
\hline SAX & NA & NA & NA \\
\hline
\end{tabular}

Source: authorial computation

In all regressions which were subject to interpretation, $\mathrm{H} 0$ was accepted on the confidence level of over $95 \%$, thus conditions for inference have been met. 
Závodný, L.: Relevance Versus Reliability Trade-off in Financial Reporting among Companies Listed at Visegrad Group Stock Exchanges. 